\title{
Religious exemptions to equality
}

\author{
Hege Skjeie $^{1}$ \\ University of Oslo, Norway
}

\begin{abstract}
The political role of religious value systems poses a great challenge in the perspective of safeguarding women's citizenship rights. This applies to all the contexts where religious law defines civil, political and social rights and obligations in a manner that systematically promotes differential treatment of women and men, girls and boys. It also applies within the framework of secular laws that protect religious freedom such that discrimination becomes a religious group right. My concern in this article is with the limits to equal citizenship that this latter kind of religious accommodation may pose. I discuss some well known commonalities between claims to group accommodation which follow from multiculturalism's minority rights reasoning, and claims to accommodation which, quite independent of "minority"“majority” statuses, follow from interpretations of the right to freedom of religion. Such accommodations are of particular relevance to the Norwegian state / religion regime, which forms the "case” under discussion here. One specific aspect of citizenship is thus in focus: The contestations over the legal protection of women's rights to non discrimination, when confronted with the protection of the right to religious freedom.
\end{abstract}

\footnotetext{
${ }^{\mathbf{1}}$ Department of Political Science, University of Oslo, Norway. PB 1097 Blindern, 0317 Oslo,Norway. hege.skjeie@stv.uio.no
} 
Gender equality law, religious freedom, human rights regimes, CEDAW, The Gender Equality Ombud.

\section{Introduction.}

Questions about the political role of religions tend to bring debates about gender justice and equal citizenship, in terms of status, participation, and belonging (cf. Siim, this volume), back to a core claim of fair laws. Globally, the political role of religions are at the centre of moral and political contestations, and religious based denial of women's equality rights is a topic of heated controversy in all international human rights forums. One important strand of feminist concern with religion is tied to the citizenship status which might follow from particular accommodation politics. The problem has been coined in general terms by Aylet Shachar as a paradox of multicultural vulnerability: Multiculturalism would actually present a threat to citizenship if pro-identity group policies, aimed at levelling the playing field among minority groups and the larger society, systematically allow the maltreatment of certain categories of group members, such as women, effectively annulling their citizenship status. (Shachar 1999:88)

The umbrella of multiculturalism, or more precisely here, the defense for minority rights, covers features which go beyond the "familiar set of common civil and political rights of individual citizenship which are protected in all liberal democracies”, Will Kymlicka and Norman Wayne state (2000:2). Minority rights expand these "familiar" notions of citizenship through a legal recognition of the distinctive identities and needs of (ethno-)cultural groups. The paradox of multicultural vulnerability occurs as the simple fact that individuals inside 
the group can be injured by the very reforms that are designed to promote their status as group members in the accommodating state (Shachar 1999).

There are interesting commonalities between accommodations which might follow from multiculturalism's “new” minority rights reasoning, and accommodations which might follow from more "familiar" reasoning about the right to religious freedom. In particular, these concern accommodation policies which grant some form of institutional autonomy to religiously defined groups. In Martha Nussbaum’s observation, liberal democracies typically hold the protection of religious freedom to be "among the most important functions of government” (2002:168). In liberal state- religion orders, the right to protection remarkably often translates into a claim for due respect for religious doctrines and customs and consequent group claims for rule-based non-interference from the state. Quite independent of "minority”-“majority” statuses, religious freedom is here understood as containing not only individual rights but corresponding group rights. Religious groups may thus be granted exemption from general laws against gender discrimination. A formalized duty for the gender equality principle to yield is imposed by the accommodating (secular) state, which this way accepts that (groups of) women have unequal citizenship rights.

Discussing dilemmas of “minorities within minorities", Anne Phillips (2005:121) distinguishes between three forms of multicultural accommodation policies: extensions, exemptions and autonomy. "Extensions" covers policies which extend to other cultural groups “privileges” previously enjoyed only by members of the majority or dominant culture - for example, extending a principle of state support for denominational schools to include 
religions associated with more recent migrants. "Exemptions" covers policies which exclude members of particular groups from requirements that are legally binding on other citizens for example, allowing types of religious dress which breach with formal dress regulations. "Autonomy" covers policies where cultural communities retain authority in the regulation of certain aspects of property or family affairs, and citizens may come under different jurisdictions depending on their religious or cultural attachments. This is, Phillips notes, the category that has been thought to throw up the hardest cases, when resulting regulations put women at a disadvantage in relation to men (2005:121).

Yet both extension and exemption policies may also provide, or lead to, more or less limited forms of group based autonomy.

Consider the citizenship regime (cf. Leibert, this volume) at work in Norway. Here the Gender Equality Act (1978) applies to all areas of society, with an explicit general exemption for the internal affairs of communities of faith (§ 2). In a new chapter on equality in working life in the Act relating to Worker Protection and Working Environment (2004), religious communities are correspondingly exempted from the general ban on discrimination on the basis of sexual orientation. And in a new law prohibiting ethnical and religiously based discrimination (2005), corresponding exemption rules accommodate religious practices. The right to discriminate for communities of faith is broadening in scope, modeled on the exemption in the Gender Equality Act, and institutionalized as a permanent right. Religious communities may discriminate as long as such discrimination is rooted in religious belief. 
“The judicial approach" to dilemmas of gender /culture/religion often overcharges actual dilemmas, Anne Phillips claims (2005). The judicial approach tends to treat (any) equality problem as related to fundamentally opposed principles of justice and fundamentally different value systems. But in many cases, there is no deep disagreement; no fundamentally opposed understandings of justice that have to be weighed, or balanced. When political theory engages with these dilemmas, hard cases are sometimes made harder than they are, in order to highlight the resolution (2005:116).

Formal exemptions from bans on discrimination, or - more generally stated - formal hierarchies of legal protection, constitute hard cases in their own right.. In Norway, the principal right to freedom from discrimination is not granted the same formal status protection as the principal right to religious freedom The Norwegian Constitution both privileges an official state religion and protects religious freedom, in one and the same article, which first establishes the right to free exercise of religion for all ( $\S 2$ of the Constitution) and then states that the Evangelical-Lutheran religion shall remain the official religion of the State. ${ }^{\text {i }}$ Corresponding rights to freedom from gender-based discrimination, ethnic discrimination or discrimination on the basis of sexual orientation are not, however, guaranteed by the Constitution, apart from the addition of an amendment (1994) establishing that it is the responsibility of the authorities of the State to respect and ensure human rights.

This responsibility is further specified through the Human Rights Act (1999). This law incorporates four international human rights conventions ratified by Norway directly into Norwegian legislation, with precedence granted to the incorporated conventions in cases 
when a conflict arises between these and other statutory provisions. These conventions have thus been given what is often referred to as "semi-constitutional" status. They integrate transnational norms on citizenship rights into national legislation (cf. Hobson et. al, this volume) in quite radical ways, although differently than through EU integration - a union Norway not is a formal member of. There are, nevertheless, certain limits set, and one important limit is reached when it comes to women's rights. Two major UN conventions are excluded from this human rights regime; ${ }^{\text {ii }}$ the Convention on the elimination of all forms of discrimination of women (CEDAW) and the Convention on the elimination of all forms of racial discrimination (ICERD). The latter is instead incorporated into a new law which prohibits ethnic and religious discrimination, while CEDAW is incorporated into the Gender Equality Act. No precedence clause applies for these conventions. When a conflict arises between CEDAW / ICERD protection and human rights' guarantees that are secured in the Human Rights Act, CEDAW / ICERD guarantees will probably have to yield. This is the formal legal hierarchy of human rights conventions in Norwegian law (Høstmælingen 2005, Holst and Skjeie 2005, Smith 2005), and sidestepping this ranking is hard to envision.

There is then, an enduring tension between the principles of gender equality and of religious freedom, here understood as a right to theologically based discrimination. This is shown in reasoning about religious accommodation, in legal weighing of human rights guarantees and in political legislative decision making. In this article, these issues are approached in two different ways. Firstly, as regards reasoning about religious accommodation, I revisit the debate over Susan Moller Okin's essay from the late 1990s: Is multiculturalism bad for women? Of central interest here is a particular controversy, between Martha Nussbaum and 
Cass Sunstein (Coen, Howard and Nussbaum 1999), as to how legal protection against gender discrimination should apply to religious communities. Nussbaum here provides what I regard as a standard defence for exemption rights, and I discuss how this defence also operates in the Norwegian context of religious exemption rights.

Secondly, I discuss how the relationship between religion and equality is treated and disputes about citizenship rights are resolved in Norwegian law. This discussion addresses prioritizing of religious freedom in constitutional guarantees, human rights legislation and the Gender Equality Act. While this legislation forms "the case” under discussion, I hope that the major points raised will be of general interest. This hope also motivates the final part of the article, which investigates actual legal and political interventions that question the current citizenship regime and point to alternatives.

\section{Should protection against gender discrimination encompass religious communities?}

Simply put, the purpose of CEDAW is to challenge the numerous variations of religious, cultural and socio-economic structures that are based on an assumption that women are inherently subordinate to men. By ratifying this convention, states commit themselves to implementing a series of measures to end discrimination against women in all forms, including incorporating the principle of equality of men and women into their legal systems, prohibiting all discrimination against women, and taking all appropriate measures to eliminate discrimination against women by any person, organisation or enterprise. 
CEDAW makes no exemption for religiously founded discrimination. The Convention's civil rights provisions are at odds with sharia regimes when they state that women shall be accorded legal capacity identical to that of men, shall have equal rights to conclude contracts and to administer property, shall be treated equally in all stages of procedures in courts and tribunals, and shall have the same rights and responsibilities as parents in all matters relating to their children. Similarly, reproductive rights - sexual autonomy, health protection during pregnancy and birth and access to contraception - remain a source of conflict between women's rights advocates and religious states and organisations.

Aylet Shachar discusses the vulnerability of women's legal rights to equality particularly in relation to family law, when proponents of multicultural accommodation and minority group leaders alike now push for legal reforms in the family law arena that would make the state adapt its institutions to reflect the cultural diversity of the citizenry (Shachar 2000:200). The same concern with women's equality rights motivated Susan Moller Okin's controversial essay Is Multiculturalism Bad for Women? (1999). Okin's criticism pointed out how various forms of protection against "external” majority decisions simultaneously allow "internal" discrimination (cf. Kymlicka 1995), with examples ranging from patriarchal rules relating to marriage, divorce, parental responsibility, inheritance, and ownership, to religion-based training and education. Shachar characterises Okin’s “simplified dichotomy” between promoting group-based interests and women's rights as "misguided”, because she fails to address the complexities of lived experiences and multiplicities of affiliations (Shachar 2000:201). Uma Narayan's critique is harsher: in this text Okin constructs all "non western cultures” as contexts whose only salient feature is that they are "oppressive to women”, 
whereby women of color, immigrant women, third world women, consequently are constructed as Prisoners, or Dupes, of their patriarchal cultures (Narayan 2205, cf. also Siim, this volume)

Okin has answered to Shacar's critique by pointing out that she did not dichotomize women's choices as an ultimatum of “..either your culture or your rights”” (2005:70-75), but stressed that policies responding to the needs and claims of patriarchal cultural or religious groups in a less patriarchal liberal context must ensure the participation in such negotiations of the less powerful members of such groups (2005:72). That is, an argument about the necessity of democratic participation.

Still, there is little doubt that Okin's criticism payed almost no attention to discriminatory doctrines and practices in what we here might call the majorities' religious cultures. Her general challenge could however be of equal relevance to majorities. Okin asked what liberal multiculturalists should do when demands for group rights, respect for differences and internal autonomy collide with women's right to equality. How can requirements for groupbased exemptions from general legal provisions be justified when they at the same time imply a violation of women's human rights? The answer, equally simply put by Okin, is that they cannot. Liberal multiculturalists need to think it through again. The liberal defence for group-based rights is only of interest in so far as it has also assessed the internal implications for women, and checked to ensure that these are also justifiable. Okin's main point is that too much of multiculturalist thinking has given this too little emphasis. Thus, an expanding normative theory has served to reproduce traditional gender blindness. And this is in spite of 
the fact that multiculturalism's theorists often link together "isms”, e.g. in different variants of “feminism and multiculturalism". According to Okin, political advocates of multiculturalism must at the very least ensure that women and men are equally represented among the parties negotiating for recognition of a group right. In later expansions of the argument, Okin makes this requirement of equal democratic participation, a primary “resolution” means (cf. Okin 2005, above).

Will Kymlicka's response offers virtually full support for Okin's concerns. A liberal approach to multiculturalism must carefully examine the potential for establishing or strengthening internal inequalities when discussing the legitimacy of group rights. Group rights that create or reinforce gender-based inequality within the group are unacceptable; a liberal theory of group rights cannot condone "internal restrictions” that generate injustice within the group. This applies to restrictions in civil and political freedoms as well as traditionalisation of social institutions (1999:31-33, cf. Kymlicka 1995). At the same time, however, Kymlicka appeals to feminism as multiculturalism's ally in a more inclusive understanding of justice - an alliance that can challenge what he calls "liberal complacencies”.

Martha Nussbaum is critical to what she calls Okin's “contempt for religion” (1999:105). According to Nussbaum, Okin views religion as little more than a bundle of superstitions bound together for the purpose of maintaining control over women. This makes it mostly a practical political issue to ensure that religion does not undermine the ban on gender-based discrimination set out in secular legislation. Nussbaum would rather highlight religion's 
potential for internal change; religion as part of radical social movements and internal religious reform movements, as she claims is the case of the Jewish reform segment to which Nussbaum herself belongs. In this sense, democratic participation is a key requirement also for Nussbaum. But she is mainly concerned with participation “within”. In Nussbaum's view, religion can legitimately demand a special form of respect from the liberal state. From this, we might reason that requirements about democratic participation in "negotiations about group rights”, such as Okin stresses, would not be similarly prioritized by Nussbaum.

Nussbaum mainly argues in line with what Anne Phillips calls "the judicial approach", and supports an interpretation of "religious freedom" which implies that that the state cannot place a substantial burden on the exercise of religion unless it can at the same time claim a compelling interest ${ }^{\mathrm{iii}}$ in so doing. The question that must then be asked is whether protection against gender-based discrimination represents such a compelling interest. Nussbaum does not, as far as I can tell, provide a clear answer to this. As long as religious organisations are voluntary organisations - with "exit" possibilities - the state should limit itself to requiring guarantees for equal freedom and equal opportunities in fundamental areas such as bodily integrity, health, political equality, freedom of speech and assembly, and the opportunity to seek employment outside the home (1999:113-114). On important aspects of religious family law she is silent, but has in other contexts listed e.g. the right to marital consent and to divorce among compelling interests (Nussbaum2000:220). Internal religious dogma and practices associated with dress codes, rituals or the choice of clerical personnel can legitimately claim freedom from the application of secular law. But all this is only valid in situations in which the members can reasonably be expected to have genuine "exit" 
possibilities. In secular, liberal states, this will be the same for all adults. Children may need extra protective measures because they lack the same "exit" opportunities.

Nussbaum's discussion employs three criteria to delimit the boundaries of religious freedom: state interest, the religious burden, and the "exit" opportunity. Such criteria are regularly used in many assessments regarding how broadly the scope of religious group rights should extend. All three appear in a defence for "the right to discriminate" provided by the chair of the Norwegian Humanist Association (Gule 2003), who supports the general exemption rights granted religious communities in Norwegian law.

Lars Gule justifies his position on the basis of a specific type of respect for human rights obligations which implies a radical prioritizing of "religious freedom". For him, the issue revolves around "what others have the right to do, even when humanists, feminists and homo-activists completely disagree in what 'the others' think, believe, say and do”. Freedom to choose a life-stance Gule portrays as "one of the oldest, most fundamental of all human rights", and "gives different people and organisations the opportunity to believe and practice their beliefs in different ways" ${ }^{\text {,iv }}$. This view is expanded upon with some comments on different types of violations that people may be subject to in a religious context. The way I understand these arguments, it is only in cases where such violations are irrevocable that the state should regulate religious practice. Differential treatment when it comes to job positions and appointments in certain organisations does not cause irreparable damage. Female circumcision, on the other hand, does. Circumcision of males causes too little harm to warrant a prohibition. More important here is that prohibiting this ritual would make it 
impossible to be Jewish or Muslim in Norway, for instance. More generally, Gule maintains that psychological damage as a result of discrimination and repression in religious communities may be difficult to prove, and will in any case exhibit great individual variation. Psychological damage can therefore not comprise a general argument for protective measures against discrimination. The "exit" opportunity is discussed in the same light. Assuming that membership of a religious community is voluntary, then the individual is free to disassociate him- or herself from the discrimination. Women and homosexuals in discriminatory religious communities can utilise their "exit" opportunity and go on to start their own congregations and religious communities. In this manner, irreconcilable demands can be reconciled: religious communities have the ability to discriminate internally, while the individual can remove herself from that group and join another, non-discriminatory organisation.

Gule's solution thus resembles Nussbaum's on several counts. Only “irrevocable violations” in "fundamental areas of life" justify state regulation of religious practices. This becomes in reality the decisive criterion. "Less fundamental" types of violations can be neutralised through the right to disassociate from them. In this blunt prescription, women's choices are actually, and starkly, presented as an ultimatum of "either your religion or your rights" (cf. Shachar/ Okin, 2005)

It is rather obvious that neither "exit" nor "voice" opportunities actually solve an acute discrimination problem. They simply bypass it. The "exit" opportunity, which plays an unquestionably central role in liberal theory regarding autonomy / subordination, thus represents an "easy way out” of this principal clash between rights. Yet what "exit" thinking 
does not contend with is firstly, what we should call an individual equal right to the exercise of faith, and furthermore, the fact that religious convictions stipulate obligations for peoples' lives. The right to disassociate can be hard enough to practice when one's identity and sense of belonging are at stake. It is at least as difficult when practical living conditions are framed in a context of inequality, whether in civil, political or social terms. Principally, the very legitimacy of forcing an "exit option" on vulnerable group members as a way of (theoretically) solving "minorities within" dilemmas, is clearly questioned in gender sensitive analyses of this option.

Conventionally speaking, however, space is clearly granted for religion based discrimination given the "exit" possibility, in popular reflections such as those expressed by Gule, in liberal theory concerning the relationship between the state and religion as discussed by Martha Nussbaum, and in actual national law making which prioritize religious group rights.

Cass Sunstein ponders the relativisation of protection against discrimination in Should Sex Equality Law Apply to Religious Institutions? (Sunstein 1999). His answer is yes, principally speaking. It should apply. Relativisation of protection against discrimination takes place through what Sunstein calls an asymmetry thesis. According to the asymmetry thesis, it is unproblematic to apply ordinary civil and criminal law to religious institutions, but problematic to apply the law forbidding sex discrimination to those institutions (Sunstein 1999:86). One cannot get away with murder, kidnapping or assault even if these are part of religious precepts or ceremonies. But there is a broad consensus regarding the limits for how far the scope of the ban on gender-based discrimination extends. It is uncontroversial to 
forbid clergymen to beat women as part of a religious ceremony, but unacceptable to prohibit gender segregation in religious educational institutions. Can this asymmetry be defended?

Sunstein discusses the justification for a "right to discriminate" as a kind of habitual defence, where protection against discrimination is routinely considered to be only "minorly important” (as opposed to "compelling”), corresponding to the view expressed by Gule in his distinction between "differential treatment” vs. "circumcision”, or Nussbaum in her focus on "fundamental" vs. "less fundamental" areas of life. This rests upon a notion that differential treatment is not a particularly harmful form of discrimination. According to Sunstein, such a defence can in principle only work, in isolated terms, as long as corresponding "minorly important" bans do not encompass religious organisations and/or practices, which as we know, is not the case. Lots of "minorly important" laws apply without modification to religious communities, without mobilising demands for exemptions. What, then, about the other element of the defence, the "substantial burden" argument? That, too, says Sunstein, can be a weak argument on its own, as long as prohibitions that reach to the core of religious practice may actually apply uncurtailed - for instance as regards ritual sacrifice of animals or ritual use of narcotic substances. In other words, general exemptions are difficult to defend. They maintain the right to discriminate as a "holy right", and that is not acceptable in a democratic society. It should be possible to introduce a ban on genderbased discrimination that also entails a break with established religious practices.

Commenting on judicial balancing acts, Sunstein notes that it is probably not possible to avoid having to weigh concrete conflicts of interests and burdens. But in many cases the decision will be easy to reach. It will only be difficult to conclude in cases where a 
compelling interest is met with a plausible claim that the interference would seriously jeopardize the continuing function of the relevant religion. But a liberal social order should prefer to deliberate difficult issues rather than to rest content with homelies about the legitimate autonomy of religious institutions (Sunstein 1999:93).

This is a view I have no problem agreeing with. Overall, I think Sunstein's "judicial approach" to interests and burdens, independent of the "exit" opportunity, is a convincing one. The "exit" opportunity is often employed as a form of standard phrase in liberal formulas of religious freedom. It borders on parody when the right to "exit" is compared to a form of religious shopping around, as in Gules visitation. For Martha Nussbaum, the exit option is clearly not to be treated light heartedly. On the other hand, she might possibly treat too lightly the force of guidelines offered by international human rights councils. In a weighing of the right to protection against gender discrimination and the right to religious freedom, the UN Human Rights Committee has explicitly rejected any interpretation of civil and political rights which would accept religion based infringements on the equal rights of women (see Loenen 2004). The general comment of the committee is entirely clear: State Parties must ensure that traditional, historical, religious or cultural attitudes are not used to justify violations of women's right to equality before the law, and to the enjoyment of all Covenant rights. The protection of religious freedom may not be relied upon to justify discrimination against women by reference to freedom of thought, conscience and religion ( HRC General Comment no. 28, March 2000). 


\section{Habitual defences: CEDAW and the Gender Equality Act.}

This guideline is not reflected in Norwegian law. As outlined in the introduction to this article, religious communities in Norway maintain the option to discriminate on the basis of gender or sexual orientation when such discrimination is rooted in religious conviction. The internal affairs of religious communities are explicitly excluded from the Gender Equality Act. At the outset, this would imply that neither the general ban on discrimination, the provisions regarding the obligation of authorities and employers to promote gender equality, the protective measures regarding employment, dismissal and pay equity set out in the Gender Equality Act, nor the provisions pertaining to equal rights to and during education, training and participation in associations, apply to the internal affairs of religious communities.

The term "internal affairs" refers to matters that are closely connected to religious practice within the relevant community. The Gender Equality Act shall not affect the manner in which a religious community practices its religion, regardless of any inherently genderspecific consequences such practice may have. This general exemption applies to the (state) majority as well as minority religious communities

The only "exception to the exception" is the protection against sexual harassment. The legislators characterize harassment as an act which is not tied to/associated with the exercise of faith/ religion. (Ot.prp.77 2000-2001:74) This is simply declared; the basis for the distinction between harassment and other forms of discrimination, and their location in different religious doctrines/dogmas/practices, is not elaborated in the law making process. In 
all probability, however, sexual harassment is also regarded as a case of what Nussbaum would classify as a fundamental area / compelling state interest (and then, consequently, as opposed to other kinds of discrimination).

The Norwegian Parliament has, on the other hand, taken a particularly strong interest in limiting the impact of religious doctrines in matters of marriage and divorce. Registered religious communities are all given formal competence to perform marriages, granted that they follow the procedures specified in the Marriage Act.. To combat situations where religious value systems still might prevent women from obtaining a religiously recognized divorce, Parliament in 2003 passed new legislation requiring signed statements from all couples about to marry, confirming that the marriage is indeed voluntary and that the spouses recognize the equal rights to divorce (The Marriage Act, § 7.1.) In the heated debate over this legislative initiative, where Muslim, Jewish and catholic communities joined in protest, no mention was however made of the general exemption clause in the Gender Equality Act. In this neglect, Parliament demonstrated its unawareness of the underlying reasons for this special treatment of religious communities, observers remarked (Thorbjørnsrud 2005). This is a clause which recognizes legal pluralism when motivated by religious belief.

The general exemption clause in the Gender Equality Act has remained unchanged since the law was adopted at the end of the 1970s. It was not evaluated when the law underwent a major revision in 2000 - 2002. A Labour Party Government was in charge of the revision. During the review process, the Labour Party's women's movement had characterised the exemption as "legitimising discrimination". But as the cabinet minister in charge of the 
proposition, the leader of the women's movement did nothing more than to state that "the issue would be examined in cooperation with the Norwegian Church.” The proposition contained no explanation of why - or how - this should be discussed with the State Church, why other religious communities should not be consulted, why gender equality and women's human rights assessments should not be included, etc. Nor did it contain any substantial assessment of the relationship between religious freedom and equality in various situations and relations. Rather, the handling of the controversy provided a prototypical instance of habitual defence, in this case narrowed down to no explicitly argued defence at all.

Norway ratified the CEDAW in 1981, but this had no ramifications for the exemption provision. The CEDAW committee, which monitors compliance with the Convention, has to no avail critiqued Norwegian authorities for not amending this part of the Act. Instead the CEDAW convention was put on hold when Parliament passed the Human Rights Act in 1999 (cf. the introduction to this article). And in February 2004, a Conservative-Christian democratic coalition cabinet decided not to ascribe CEDAW the same legal status as other human rights conventions have been given in Norwegian legislation. In May 2005, the parliamentary majority confirmed this decision. The explicitly stated reason for this formalized first order - second order status of human rights conventions was not, however, the challenge posed by CEDAW to the privileged position of religion in Norwegian law. Rather, the cabinet cited a final report from a large scale government appointed "Power and Democracy study "as the prime reason behind this move (St.mld. 17 (2004-2005), cf. Ot.prp. 33 (2004-2005), Ot.prp. 35 (2004-2005)). This report states that the Norwegian political system is in a process of fragmentation, where "democracy", understood as national majority rule through party political representation and formal chain of governance, is in a process of 
disintegration. Many processes of change were interpreted as pointing in this same direction. In particular, however, this main conclusion stressed an increase in legislation on citizen rights as contributing to a trend in which courts take control of political issues. It directly addressed the human rights regime: When human rights conventions are incorporated in Norwegian law, the rulings of international courts become increasingly important in defining the limits of national political decision making power. The report made the increasingly familiar claim: The expansion of legally binding human rights regimes poses a threat to “democracy by popular will”. (NOU 2003:19, Østerud, Engelstad and Selle 2003)

As a member of the research committee appointed by the government to chair this study I issued a dissenting report (also published in NOU 2003:19), principally contesting the notion that application of international human rights conventions could be unambiguously stated as a loss, or "shrinking” of democracy, and furthermore, arguing specifically for the importance of CEDAW in securing women's equality rights when situations of conflicting rights otherwise occur. The issue of CEDAW's formal status in Norwegian law went through an extensive process of review and comment. Virtually all of the institutions and agencies consulted during the review process in 2003 recommended that the convention be incorporated into the Human Rights Act. Only two were negative: the Legislation Department at the Ministry of Justice and the Office of the Attorney General. Both declared that they were deeply worried about the relationship between "judicialisation and the overall political room to manouvere”. In this way, the actual operation of an asymmetry thesis in political decision making is also revealed: The stated objections to the incorporation of the CEDAW into the Human Rights Act are not based on any form of substantive evaluation of 
the significance of the convention's equality principles. Incorporation is instead rejected on the basis of general, unsubstantiated, considerations about the danger of institutional power shifts.

\section{Interventions: Priesthoods and religious education}

We see how a conventional understanding of religious freedom as a kind of institutional autonomy justifies the exemption from the general ban on gender discrimination in Norway. The exemption clause does not differentiate between religious communities, and does not take into account the particular position of the State Church. This way, an issue of principal importance to the established state-religion order is simply ignored. On what precise grounds could autonomy be claimed in this case? An "external protection" defence (cf. Nussbaum 1999, Kymlicka 1995) would imply that a ban on discrimination actually threatened the church's existence. It seems, however, rather farfetched to invoke a special need for state protection of the state church's distinctiveness and/or traditional character. The State Church is the institutional guardian of the official religion of the state, and the state is thereby woven into the fabric of the activities of the institution as a whole. This relationship is in itself problematic in human rights terms. Independently, it clearly gives the state an interest in church affairs that in principle cannot be described as only "minorly important". Neither can, in principle, the discrimination issue . This follows both from the strengthening of international human rights regimes and from national anti-discrimination policy, the argument being equally valid for gender discrimination and discrimination on the basis of sexual orientation. 
Interestingly, in the first draft of the Gender Equality Act, which was presented in 1974, the State Church was not part of the planned exemption. The exemption was primarily designed for religious groups that in the 1970s were still called “dissenter groups.” Within the State Church, discrimination would be prohibited and the Act would apply with no exceptions of any kind. But when the draft was sent out for review, the country’s bishops, the Norwegian Lutheran School of Theology and the Faculty of Theology at the university mobilised a series of protests that ended up in the department for church affairs. In the 1970s, the ministerial training programme at the Norwegian Lutheran School of Theology was not open to women, nor was the teachers' council interested in being forced to allow women to take part in the practical-theological seminar. The protests from the church were met in the sense that the exemption for the internal affairs of religious communities in the draft Act was expanded to encompass the State Church as well. But the Government was not willing to allow the educational institutions an exception from the general ban on discrimination. A direct confrontation was nonetheless avoided when the School of Theology chose, in 1977, to open its ministerial training programme to women. In this respect, a state initiative in clear breach with established religious practices (cf. Sunstein 1999), succeeded to change the internal rules on gender discrimination.

In his official response to the suggested revision of the Gender Equality Act in 2000, the Bishop of Oslo emphasised the overall importance of the Act in setting new norms for the Church. He argued much in line with Nussbaum's reasoning on the importance of internal religious reform, but his conclusion was contrary. The bishop argued that the general exemption for the internal affairs of religious communities should not be maintained vis-à-vis 
the State Church. "It is difficult to envision how the Gender Equality Act today would entail ramifications that principally go against the grain of the Church of Norway as a religious community. The equality principle must be said to be in keeping with the gospel. Justice and equality regardless of race, class or gender is one of the pillars of Christian teaching. Laws that are based on this principle must also be applied within the Church," wrote the bishop. ${ }^{\mathrm{v}}$. In this, he was clearly out of line with collegial church bodies. The leadership of the Church of Norway National Council has stated on several occasions that the exemtion in the Gender Equality Act must be maintained ${ }^{\mathrm{vi}}$. This is primarily out of consideration for the "minority within the Church" who take the view that women should not be given clerical preaching responsibilities. The bishop could, however, rely on the support of most women church leaders. In a survey where we asked whether the Gender Equality Act should apply to the Church of Norway, more than two thirds of the women in prominent leadership positions within the church answered affirmatively, while less than one third of their male colleques did the same. Women in leadership positions are however in a very clear minority within the church (Skjeie and Teigen 2003). In other words, had Okin’s “negotiation” requirements been fully applied to a situation where this particular group right was contemplated, the outcome would probably be an annulment.

The Gender Equality Ombud has repeatedly asked that the general exemption provision in the Gender Equality Act be repealed, but to no avail. She also relies on the legal implications of "internal reform". The starting point is that the legislative history of the Gender Equality Act explicitly states that employment of the clergy in the Church of Norway is exempted from the scope of the Act. At the same time, these documents indicate that the question of 
whether an activity can be defined as belonging to the internal affairs of a religious community is to some degree based on discretion. If a religious community for religious reasons excludes women from certain rituals, the exemption provision may be invoked, states the Ombud. But today, there are no church-related actions that are not carried out by women. And the Church's own employment regulations give women and men equal access to clerical positions. Discrimination can therefore not in general be said to have any "direct connection to the exercise of the religion" in the Church of Norway. Thus, the Ombud concludes that the prerequisite for assuming as a general rule that clerical appointments are encompassed by the exemption provision of the Gender Equality Act can no longer be said to exist.

The Ombud's evaluation, however, also specifies how a potential religious right to discrimination might, in accordance with the law, be claimed as a form of (limited) group right. In a concrete assessment, associated with a possible appeals case, it will only be a congregation that may be protected by the exemption for the internal affairs of religious communities. In other words, it is the congregation that has to claim the right to discrimination; it is the congregation that must collectively believe that the employment of women is in conflict with the congregation's religious convictions. In an appeals case it will be up to the congregation to document this. For women who are already employed in clerical positions in the Church of Norway, the Gender Equality Act applies in full. They are thus entitled to the same working conditions as their male colleagues. Male clergy who object to women in clerical positions cannot invoke the exemption provision of the Gender Equality Act when they (on their own, within their respective congregations) refuse to participate in church activities together with women clergy. Since it is the employer's responsibility to 
ensure that women in the church are not subjected to discrimination, the solution must be that those who object to women ministers must yield ${ }^{\text {vii }}$.

The appeals board for gender equality has dealt with only one case in which the question of the boundaries of religious freedom is explicitly raised. This involved religion-based education - an issue that in many religious communities, in various ways, regularly comes into conflict with the ban on discrimination. Religion-based educational discrimination may comprise refusing girls the right to equal education, gender-segregated forms of teaching, or the dissemination of gender stereotypes or doctrines of subordination through teaching . The case dealt with by the appeals board involved the latter - the legality of teaching materials in Christian private schools employing Accelerated Christian Education (ACE teaching), which is an educational programme utilising materials developed in American Christian communities of faith (also cf. Borchgrevink 2002). In this case, the appeals board drew up a basis for the delimitation of religious group rights which incorporates the European Convention on Human Rights, the Covenant on Civil and Political Rights and the CEDAW in its considerations. But there was still dissent in relation to these conclusions.

The Gender Equality Act stipulates that teaching materials used in schools and teaching institutions shall be based on gender equality. After reviewing the ACE teaching materials, the Ombud concluded that they were in contravention of the Act. The teaching materials in all subjects were predicated on religious assumptions about the subordinate role of women. Relevant examples were taken from the materials for tenth-grade level social studies: 
God finished His creation, and He saw that it was good. There was just one exception: It was not good for Man to be alone. Man needed close fellowship with other people to prevent him from feeling lonely. To meet this need, God created Woman and wrought the Family.

Other examples were taken from the fourth-grade level social studies:

Multiple choice - wives shall obey their husbands - underline the best answer:

- Wives will be (sorry, sad, happy) to subordinate themselves to their husbands.

- (Wives, dogs, cats) shall obey their husbands.

- A wife obeys God when (he, she, it) obeys a husband.

ACE Norway referred to the constitutional right to freedom of religion, the general exemption in the Gender Equality Act for the internal affairs of religious communities and the right of parents to raise their children within the religious belief system of their choice. One of the rectors submitted the following brief statement on what he regarded a proper hierarchy of rights in this respect: "The Gender Equality Act must be subordinate to the freedom of expression, the freedom of religion and the rights of parents. Anything else would be impossible in a democracy” (cited from Borchgrevink 2002:156). The Ombud's decision was sent to the appeals board for gender equality, which provided majority and minority statements. The majority consisted of women, the minority of men. The majority found that the submissive portrayal of the wife in the ACE fourth-grade teaching materials represented a breach of the fundamental idea underlying the Gender Equality Act, as well as of the 
provisions of the CEDAW concerning state obligations to prevent traditional cultural stereotyping. The minority maintained that the teaching materials were protected by the principle of religious freedom, and that this principle should weigh more heavily than the right to equality.

\section{Expression of religious belief: Hijab in the work place}

During the whole period that the Gender Equality Act has been in effect - that is for 25 years - the Ombud has identified only three instances where a violation of the ban on gender discrimination on ethnic and minority religious grounds are claimed. ${ }^{\text {viii }}$ Two of the three instances address hijab discrimination. ${ }^{\text {ix }}$

Hijab now provides the symbolic ground for controversy raging all over Europe (see Saharso in this volume). In this controversy, the headscarf is made up to address a whole range of liberal principles: state neutrality, gender equality, religious freedom, religious diversity, multicultural accommodation. It is played out on a number of arenas: in schools, work places, public offices and courts. Court decisions on hijab prohibitions vary across Europe. Two complaints of hijab discrimination has been tried before the European Court on Human Rights. In both cases the state decisions to impose prohibition were upheld. In one case (Dahab v. Switzerland), concerning a teacher's use of hijab, the court gave priority to the right of pupils to receive education in a religiously neutral context. In the other case (Sahin v. Turkey), concerning a university student's use of hijab, the court gave priority to the role of the national decision making body in evaluating the necessity of a ban on the use of religious symbols in teaching institutions. But in both cases, the court also stressed that it found the 
use of headscarves hard to square with the principle of gender equality - clearly interpreting headscarves in general as a symbol of religiously based subordination (Loenen 2004). ${ }^{\mathrm{x}}$ In "Sahin v. Turkey", the court further stressed the protection of "the rights and freedoms of others"; the impact which wearing such a symbol, presented or perceived as a religious duty, may have on those who chose not to wear it.

These general comments were repeated in a Grand Chamber ruling in November 2005. The one dissenting judge heavily criticised the majority’s treatment of hijab and gender equality. The court had made an unsubstantiated claim, a purely abstract weighing of conserns: "What - in fact - is the connection between the ban and sexual equality? The judgement does not say” (http://cmiskp.echr.coe.int). The dissenting judge characterized the "general, abstract" gender equality appraisals as being clearly outside the Court's role.

There can be little doubt that the European Human Rights Court's general comments on headscarves and gender equality principles contribute to challenge decisions where hijab prohibitions, quite contrary, have been held to violate gender equality principles. In a number of countries, the prohibiting of headscarves in either schools or work places has been regarded as a form of illegal, non justifiable, religious discrimination. In Norway, hijab bans in the work place have also been ruled to be in violation of the Gender Equality Act. In the Norwegian cases, it is the discriminatory effects of hijab bans on women employees which have been at the forefront, and the individual woman's right to non-discrimination in the labour market has decided the matter. No general statements on the symbolic meaning of Muslim head coverings, like those offered by the European Human Rights Court, have been presented. Like the Swedish Ombud for protection against ethnic discrimination, the 
Norwegian Gender Equality Ombud has regarded such general assessments as being outside the capacity of the office, and an inappropriate judgement of individual beliefs.

One case of hijab discrimination was brought before the appeals board, which holds the decision power in matters of continued dispute. A large hotel in the Oslo area had practised an employee uniform code which the hotel management claimed was not reconcilable with the use of head coverings. The appeals board agreed with the Ombud in her evaluation that this prohibition mainly would have negative consequences for women employees using hijab. The uniform code - although gender neutral in wording - produced gender specific discriminatory effects, and was thus in breach of the prohibition against indirect discrimination in the Gender Equality Act. The hotel accordingly changed its uniform code. The most recent case concerns a large furniture store were the management demanded "scarf off" for one of the employees, again with reference to internal dress code regulations. In correspondence with the Ombud, the employer also stated that they established the dress code from a desire to secure "value neutrality". The Ombud, on the other hand, found that the business' character and the employee's type of work (selling furniture) to be in no particular need of securing spiritual value-neutrality. The ruling upheld a hijab prohibition as illegal gender discrimination (Mile 2004). ${ }^{\text {xi }}$

It is the use of hijab in formally non religious settings which is debated in these cases. In this sense, "hijab" does not construct a situation where gender discrimination follows from religiously motivated claims to institutional autonomy. Could there still be a "multicultural paradox" present in decisions which support the use of hijab? Could such rulings be seen as a 
special protection of religious groups which in effect put (new) restrictions on women's rights to equal citizenship? This is the argument made by the Human Rights Court in Strasbourg - or "the converse implication” drawn, if we follow the dissenting judge in Sahin v. Turkey. In particular, this is clear from the court's references to the "rights and freedoms of others”. In the court's opinion, the choices of some women, who wear the headscarf, may put undue pressure on other women, who would prefer not to wear it. This thinking about "restrictions" is, at best, one sided. Another side is presented in the Norwegian Gender Equality Ombud's consideration: a hijab ban would disproportionately hamper religious women's employment opportunities. There is little doubt that a head scarf ban implies a decision not to accommodate specific religious beliefs and / or religious groups in otherwise non religious settings. But it does not thereby automatically imply a decision to prioritize gender equality.

\section{Conclusion}

My concern in this article has been with the limits to women's equal citizenship that religious accommodation policies may pose. I have discussed some commonalities between group accommodations which follow from multiculturalism's minority rights reasoning, and group accommodations which follow from habitual reasoning about freedom of religion. The article has concentrated on one aspect of democratic citizenship: the contestations over the legal protection of women's rights to non discrimination when confronted with the protection of the right to religious freedom. 
The historical traditions of major world religions have been characterised by a belief in hierarchically ordered, gender-specific rights and obligations. Women's equal citizenship rights are challenged when current state-society orders provide general exemptions from general bans on gender discrimination for religious communities. Protection against discrimination on the basis of gender, race, culture, religion, ethnic group, or sexual orientation is a pillar of human rights thinking. Increasingly, international human rights policies are discussing parallel, and intersecting, discriminatory cultures - sexism, racism, homophobia - as well as collision between sets of rights in relation to religion-based rights and protection against gender discrimination and discrimination based on sexual orientation. In an important weighing of the right to protection against gender discrimination and the right to religious freedom, the UN Human Rights Committee has explicitly rejected any interpretation of civil and political rights which would accept religion based infringements on the equal rights of women. This requirement clearly follows from CEDAW statutes.

Norwegian legislators still go a long way in the direction of conferring privilege on religious freedom. This can be seen in the combination of an official state religion and legally granted freedoms to discriminate for religious communities. Actually, the granting of formal exemption rights is currently broadening in scope and institutionalized as a set of permanent rights. New legal provisions to restrict the impact of religious value systems on women's rights in marriage and divorce, could be seen to point in the opposite direction. But the actual political history of this provision primarily speaks of intentions to target informal legal pluralism, and the cultural impact of Islamic family law. The formal expansion of general exemption rights in anti discrimination legislation, on the other hand, primarily seems to be 
motivated by a will to protect the majority religion and the official State Church. But the political defence of religious rights to discriminate are also challenged by legal interpretations which for instance question the status of the Lutheran State Church as regards exemption rights, in particular the right to discriminate against women in clerical preaching positions. Also, religion-based teaching in private schools which propounds subordination of women is held in violation of the Gender Equality Act. At the same time, general questions about internal religious subordination dogmas have been deemed irrelevant in legal readings of controversial hijab cases, where women employees have met employer demands of "scarf off”. The decisions in hijab cases in Norway simultaneously upheld women's equal rights to religious expression, and to non discrimination in the work place. This line of reasoning represents a more gender sensitive approach than the hijab rulings recently presented by the European Human Rights Court in Strasbourg. In these rulings, the court itself seems to construct a decision situation where rights collide - the particular woman's right to religious expression vs. any (other) women’s right to gender equality.

As far as "judicial approaches" to gender equality go, I am thus in favour of approaches which abstain from efforts to balance “fundamentally opposing” values where no such opposition is claimed. I am also much in favour of gender equality laws which makes no exception to its own basic principle. When the state grants general exemption rights from anti discrimination legislation to religious communities, it has unilaterally sided with the “majorities within”, and formally imposed on gender equality a duty to yield. 


\section{References}

Bergem, K.., Karlsen, G. \& Slydal, E. (2002) Menneskerettigheter - en innføring (Oslo: Humanist forlag).

Borchgrevink, T. (2002) Likestilling, det flerkulturelle demokratiets hodepine, in: G.

Brochmann, T. Borchgrevink \& J. Rogstad (Eds) Sand i maskineriet, pp. 146-173 (Oslo: Gyldendal Akademisk).

Gule, L.(2003) Retten til å diskriminere. Samtiden (3-2003).

Holst, C. \& Skjeie, H. (2005) Vikeplikt 2005. Dagbladet (23.04.2005)

Høstmælingen, N. (2005) Annenrangs menneskerettigheter for kvinner og etniske minoriteter? Morgenbladet (14.-21.04.2005)

Kymlicka,W. (1995) Multicultural Citizenship (Oxford: Oxford University Press).

Kymlicka, W. (1999) Liberal Complacencies, in: J. Coen, M. Howard \& M. Nussbaum (Eds) Is Multiculturalism Bad for Women? Susan Moller Okin with Respondents, pp. 31-34 (Princeton: Princeton University Press).

Kymlicka, W.\& Norman, W. (2000) Citizenship in Diverse Societies (Oxford: Oxford University Press).

Leonen, T. (2004) Women caught between religion and equality? Developments in international and European human rights law. Paper at the European Science Foundation conference: The Impact of of cultural and religious gender models in the European formation of socio-political human rights. Rome: November 2004. 
Mile, K. (2004) Diskriminering av kvinner, in: N.. Høstmælingen (Ed): Hijab i Norge trussel eller menneskerettighet? pp. 220-230 (Oslo: Abstrakt forlag).

Narayan, U. (2005) The politics of forgetting, the politics of rescue and global institutional racism - shining some light on the dark side of contemporary feminism. Keynote address at the international conference: Crossroads - debating women's rights, racism and religion, University of Oslo, Oslo: May 2005.

NOU 2003:19 Makt og demokrati. Sluttrapport fra Makt- og demokratiutredningen

Nussbaum, M. (1999) A Plea for Difficulty, in: J. Coen, M. Howard \& M. Nussbaum (Eds.):

Is Multiculturalism Bad for Women? Susan Moller Okin with Respondents, pp.105-114 (Princeton: Princeton University Press).

Nussbaum, M. (2000) Women and Human Development (Cambridge: Cambridge University Press).

Okin, S.M. (1999) Is Multiculturalism Bad for Women?, in J. Coen, M.Howard \& M.. Nussbaum (Eds) Is Multiculturalism Bad for Women? Susan Moller Okin with Respondents, pp. 7-24 . (Princeton: Princeton University Press).

Okin, S.M. (2005) Multiculturalism and feminism: no simple question, no simple answers, in: A. Eisenberg \& J. Spinner-Havel (Eds) Minorities within minorities. Equality, Rights and Diversity, pp. 67-89. (Cambridge: Cambridge University Press)

Phillips, A. (2005) Dilemmas of gender and culture: the judge, the democrat and the political activist, in: A. Eisenberg \& J. Spinner-Havel (Eds) Minorities within minorities. Equality, Rights and Diversity, pp. 113-134. (Cambridge: Cambridge University Press)

Shachar, A. (1999) The Paradox of Multicultural Vulnerability: Individual Rights, Identity Groups, and the State, in: C. Joppke and S. Lukes (Eds) Multicultural Questions, pp. 87-111 (Oxford: Oxford University Press) 
Shachar, A. (2000)Should Church and State be joined at the Altar? Women's rights and the multicultural Dilemma, in: W. Kymlicka \& W. Norman (Eds) Citizenship in Diverse Societies, pp. 199-223 (Oxford: Oxford University Press).

Skjeie, H. \& M. Teigen (2003) Menn i mellom. Mannsdominans og likestillingspolitikk (Oslo: Gyldendal Akademisk).

Sunstein, C. (1999) Should Sex Equality Law Apply to Religious Institutions?, in: J. Coen, M. Howard \& M. Nussbaum (Eds) Is Multiculturalism Bad for Women? Susan Moller Okin with Respondents, pp.... (Princeton: Princeton University Press).

Thorbjørnsrud, B.S (2005) Evig din? Ekteskaps- og samlivstradisjoner i det flerreligiøse Norge (Oslo: Abstrakt forlag).

Østerud, Ø., F. Engelstad \& P. Selle (2003) Makten og demokratiet. En sluttbok fra Makt- og demokratiutredningen (Oslo: Gyldendal Akademisk).

\footnotetext{
i. In the original text, the stipulation concerning state religion, was accompanied by the following religiously defined expulsions: Jesuits and monastic orders were not to be tolerated, and Jews were not granted permission to access the country at all. See Bergem, Karlsen and Slydal, 2002. The state religion is accompanied by a state church, a Christian intention clause for public schools and kinder gardens, and a compulsory education program in the subject ("teaching of":) Christianity, Religion and Life Stances This compulsory program was found in breach of the Convention on Civil and Political Rights by the UN Human Rights Committee in Geneva in November 2004. In January 2006, a government appointed committee delivered its recommendations on the abolishment of the constitutionally anchored state religion and the development of a new legal framework for the Church of Norway .

ii The Human Rights Act incorporate the European Convention on Human Rights, the covenants on civil, political, economic, social and cultural rights, and the Convention on the Rights of the Child.

iii Nussbaum 1999:111. The alteration of this approach in a US Supreme Court decision made in 1990 is a major theme in Nussbaum's discussion. The new ruling stated that a neutral (non-discriminatory) law does not conflict with the protection of the right to religious freedom ascertained in the constitution even if the state hardly could be considered to hold a "compelling interest". The issue concerned whether the use of a narcotic substance during a religious ceremony could claim exception from a general legal ban.

${ }^{\mathrm{iv}}$ Quoted from the internet version; www.samtiden.no/03-3/art4.html, s.2.

${ }^{v}$ Letter from the Bishopric of Oslo, dated 7.Feb. 2000.

${ }^{v i}$ Cf. The Church of Norway National Council's memorandum dated 27.Jan. 2000.

vii Letter from the Gender Equality Ombud addressed to church organizations, 22.Nov. 2002.
} 
viii Statistics provided by the Equality Ombud's office for this article. Statistics should not be interpreted as proof of general societal lack of discrimination on these grounds; the Gender Equality Act does little to specify protection against discrimination on combinatory grounds. This issue was strongly raised by immigrant women's organisations during the revision process in 2000-2002. It was rejected by the Ombud with reference to the general clause (but - alas - with no reference to the general exemption). Recently however, the problem of combined discrimination has provided one of the main arguments for a reform of the Ombud institution: A new agency was established in 2006, to oversee both the Gender Equality Act and the new law against discrimination on ethnic and religious grounds.

ix The first of these were a collection of 14 different complaints, presented by the Norwegian Centre against Ethnic Discrimination, the MIRA Centre and the Islamic Women's Group. Those cases which were actually possible to investigate resulted in a decision by the Ombud that the prohibition was in violation of the Gender Equality Act (Mile 2004:222-223)

${ }^{x}$ Dahlab v. Switzerland is from2001, decision on admissibility - found non admissable and Sahin v.

Turkey from 2004. Titia Leonen (2004) discusses the main "pro-con" arguments of hijab controversy, and also make note of the German constitutional court's contrary decision on a teacher's complaint from 2003. The Sahin v. Turkey decision was upheld in a Grand Chamber ruling in November 2005.

${ }^{x i}$ Note that this approach differs on several accounts from the decision by the Danish Supreme Court in the "Føtex case" about religious discrimination, from January 2005. The Supreme Court ruled in favour of the store chain s uniform code, which prohibited any type of head covering and, more generally, all forms of religious and political symbols.

\section{Biography:}

Hege Skjeie, dr.polit. Professor at the Department of Political Science, University of Oslo, Norway.

\section{Recent publications:}

Gender Equality: On Travel Metaphors and Duties to Yield. In Sirkku Hellsten, Anne Maria Holli and Krassimira Daskalova (eds.): Women's Citizenship and Political Rights. London, Palgrave, 2005 pp. 86-104

Political Constructions of Gender Equality: “Traveling towards.. a Gender Balanced Society?”. With Mari Teigen. In NORA no. 3, 2005.

Nødvendig - Nyttig - Rettferdig? Likestillingsargumenter i offentlig debatt, i Kvinder, Køn og Forskning. No. 4, 2005: 30-41. With Mari Teigen

The Nordic Countries: An Incremental Model. In Drude Dahlerup (ed): Women, Quotas and Politics. London, Routledge, 2005 pp. 55-82. With Drude Dahlerup and Lenita Freidenvall.

The Scandinavian Model of Citizenship and Feminist Debate, in Richard Bellamy, Dario Castiglione and Emillio Santoro (eds): Lineages of European Citizenship: Rights, Belonging and Participation in Eleven Nation-States. London, Palgrave 2004 (148-166). With Birte Siim.

Changing Patterns of Gender and Power in Society, In NIKK Magasin, no. 3, 2003 pp. 5-12. With Anette Borchorst.

Demokrati, makt og menneskerettigheter. I NOU 2003:19: Makt og demokrati pp. 74-87

Menn imellom. Mannsdominans og likestillingspolitikk. Gyldendal Akademisk 2003. With Mari Teigen. 